Prace Literackie LX

Wrocław 2021

https://doi.org/10.19195/0079-4767.60.3

HANNA MIERA

ORCID: 0000-0001-5627-0577

Uniwersytet Wrocławski

\title{
Samotność przemijania. Synteza biograficzna schyłku życia Elizy Orzeszkowej
}

wielki motyl powietrzem płynął, powoli, ciężko, płynął ku oblubieńcom, za sobą wiodąc ruchliwy, wirujący rój motyli mniejszych, lżejszych, żółtawych, błękitnawych, liliowych, białych... Wtedy-to stało się coś — okropnego! Kukułka [...] jak szalona, jak obłąkana, krzyczeć zaczęła [...] — Śmierć idzie! Śmierć idzie! Śmierć idzie! ${ }^{1}$

E. Orzeszkowa

„Przechylam się w ogóle bardziej na stronę pesymizmu niż optymizmu i zdaje się, że gdybym znała Hartmanna, żyć bym z nim mogła w serdecznej zgodzie uczuć i myśli" ${ }^{2}$ pisała Eliza Orzeszkowa w 1881 roku w liście do Franciszka Rawity-Gawrońskiego. Samotność towarzyszyła pisarce niemal od zawsze. Mówiła o sobie: „nerwy od dzieciństwa już czułe jak ostateczne mazgajstwo i rozczochrane jak włosy na wichrze"3. Przyczyny tego upatrywała we wrodzonej skłonności do melancholii. Od najmłodszych lat doświadczała niezrozumiałych dla niej napadów smutku i tęsknoty, które w późniejszym okresie życia przerodziły się w trwające czasem tygodniami, a nawet miesiącami stany melancholii, „letargi duchowe”. Przez całe życie zmagała się z poczuciem nieuchronnej utraty najważniejszych dla niej osób, miejsc, rzeczy.

Około lat dwudziestu [...] uczułam znowu, że jestem sama i że nikt z tych, którzy mię otaczali, naprawdę nie kochał mię nigdy i nie kocha. Ten to, jak mniemam, brak miłości, w dzieciństwie i najpierwszej mojej młodości panujący, sprowadził dwa następstwa całym już moim życiem rządzić

${ }^{1}$ E. Orzeszkowa, Wesele Wiesiotka, [w:] eadem, Chwile, Warszawa 1901, s. 195.

2 E. Orzeszkowa, Listy zebrane, t. 3, oprac. E. Jankowski, Wrocław 1956, s. 123.

3 E. Jankowski, Eliza Orzeszkowa, Warszawa 1966, s. 22. 
mające: rozmiłowanie się w książkach, w nauce, w świecie własnej a bujnej fantazji, które mię pocieszały i uspokajały — i wielki smutek serca, które dziwiąc się samotności swojej, wyjść z niej pragnęło ${ }^{4}$.

Aureli Drogoszewski w studium poświęconym Orzeszkowej zauważył: „nie umiała [...] nigdy śmiać się wesoło. Niekiedy tylko łagodnie się uśmiechała. Ból i smutek w duszy jej był gościem częstym"5. W liście do Nikodema Erazma Iwanowskiego wspominała:

Jestem już starą, ale pochwalić się tym mogę, że i za młodu nie lubiłam nigdy siedzieć po męsku ani po turecku, a myłam się i czesałam zawsze tak, jak Pan Bóg przykazał. Jedno tylko przyzwyczajenie mam fatalne. Palę papierosy. Nauczyła mię tego głęboka samotność, w której spędziłam sześć lat bardzo młodych, bo od 21 do 27 -go roku życia [...]. W latach tych ciszy niemal grobowej, samotności bezbrzeżnej i ciągłego wewnętrznego płaczu nad sobą i nie nad sobą nauczyłam się czytać, pisać i - papierosy palić. Wszystkie te trzy rzeczy robię aż dotąd ${ }^{6}$.

U kresu życia pisarka pogrąża się w melancholii. Staje się uwrażliwiona na przemijanie. Nie potrafi się pogodzić ze śmiercią Nahorskiego, mijający czas w żaden sposób nie łagodzi jej bólu. Szuka atencji u debiutujących pisarzy, przeżywa także zauroczenie znacznie od niej młodszymi mężczyznami: Franciszkiem Godlewskim, Tadeuszem Garbowskim oraz Tadeuszem Bochwicem. Pisze do nich długie, intymne listy, cechujące się nieraz pensjonarskim zawstydzeniem, niewiele mającym wspólnego z jej wiekiem. Nazywana „samotnicą z Grodna”, nigdy nie założyła własnej rodziny:

życie domowe z ludźmi obcymi [...] właściwie oznacza brak życia domowego, więc mniejsze lub większe utrudzenie serca i umysłu bez odpowiedniej kompensaty w cieple serdecznym i zadowoleniu umysłowym ${ }^{7}$.

Początek XX wieku staje się w jej twórczości czasem rozważań, biorących się z wydarzeń rewolucji rosyjskiej, pogłębia się także kryzys ideowy pisarki, a stan jej zdrowia znacznie się pogarsza ${ }^{8}$. Z niechęcią odbywa kilka podróży ,do wód". Ostatni etap życia Orzeszkowej to czas podsumowań. Z jej pism wyziera żal, lęk, rozpaczliwa samotność, pragnienie bliskiej śmierci.

Egzystencjalne doświadczenie smutku pojawia się niemal we wszystkich jej późnych utworach. Ale i we wcześniejszej twórczości możemy odnaleźć całe spektrum bohaterów ogarniętych melancholią. Również bogata epistolografia pisarki przesiąknięta jest motywami śmierci, cierpienia, samotności. W niemal obsesyjny sposób pojawiają się w niej pytania natury egzystencjalnej, przepla-

${ }^{4}$ E. Orzeszkowa, Listy zebrane, t. 9, Wrocław 1981, s. 67.

5 A. Drogoszewski, Eliza Orzeszkowa, [w:] E. Orzeszkowa, Pisma, t. 1, Warszawa 1912, s. LXXXIV.

${ }^{6}$ E. Orzeszkowa, Listy zebrane, t. 9, s. 54-55.

7 E. Orzeszkowa, Listy zebrane, t. 4, Wrocław 1958, s. 137.

8 Por. M. Skiba, O życiu, cierpieniu i śmierci. Epistolograficzne rozważania egzystencjalne Orzeszkowej, [w:] Poznawanie Orzeszkowej. W stulecie śmierci (1910-2010), red. I. Sikora, A. Narolska, Częstochowa-Zielona Góra 2010, s. 371. 
tane wspomnieniami z przeszłości ${ }^{9}$. W jednym z listów do Tadeusza Bochwica, w pierwszym dniu 1909 roku, Orzeszkowa pisze: „A teraz cisza grobowa w domu i za domem [...] obiad zapewne sama jedna jeść będę [...]"10. Do motywu „ciszy grobowej" nawiązywała wielokrotnie ${ }^{11}$. Korespondencja miała w jej życiu ogromne znaczenie. Wymieniała setki listów z przyjaciółmi, krewnymi, literatami, publicystami, ludźmi nauki. Nie wszystkie one obfitowały jednak w głębokie zwierzenia. Orzeszkowa bardzo niechętnie „otwierała się” przed ludźmi. W liście do Jana Karłowicza wspominała: „Choruję prawie na nieśmiałość i małą ufność w siebie i obudzane dla siebie uczucia ludzkie"12. Większość upublicznianych $\mathrm{w}$ korespondencji informacji była przez nią starannie selekcjonowana. W jednym z listów do Marii Konopnickiej, z którą przez bez mała trzydzieści lat łączyła Orzeszkową przyjaźń, tłumaczyła się: „Piszesz, Najdroższa, abym Ci wiele pisała o sobie. Naturalnie, że przed nikim nie otwierałabym serca na oścież tak chętnie, tak ufnie, jak przed Tobą — gdybym umiała. Już nie umiem; od nieużywania drzwi zardzewiały"13. Ze swoich uczuć ujawniała wyłącznie tyle, ile chciała ujawnić. Tym bardziej uderza rozpacz bijąca z listu do Tadeusza Bochwica:

Wczoraj i dziś duszę zalewa mi smutek dziwny, bezdenny, tak niszczący energię i wszystkie chęci, że pisanie rozpoczęte, i nawet pilne, leży na stronie — dokończyć go nie mogę. Takie czarne fale przychodzą czasem - skąd? ach, zewsząd! $Z$ tego, co minęło, i z tego, co nadejść musi, ze zwątpień, zniechęcenia, wątłości wszystkiego, co na ziemi, z głuszy rozlegającej się dookoła serca i dookoła myśli. [...] zmagam się z kamieniem grobowym, który przykrył mi aż do ostatniego śladu wszelką dobrą nadzieję, i zmagając się tak w milczeniu, w tajemnicy absolutnej, cierpię bardzo. Wieko tajemnicy przed Panem tylko podnoszę [...] i proszę o nieczytane tego ustępu listu mego nikomu. Sercu i honorowi Pana prośbę tę powierzam ${ }^{14}$.

„Czarne fale" z czasem pojawiają się z większą częstotliwością i pisarce coraz trudniej z nimi walczyć. Rozrachunek z przeszłością nie przynosi pocieszenia, lata pracy literackiej, działalności oświatowej, szerzenia polskości, znajdujące uznanie w społeczeństwie, nie znajdują go w jej własnych oczach. O samej sobie Orzeszkowa pisze bardzo krytycznie, nawet mimo licznych sukcesów literackich, zwraca uwagę na braki w swoim wykształceniu, ma poczucie niższości, marności, znikomości w porównaniu z innymi ludźmi ${ }^{15}$. Dlatego przez całe życie nie ustaje w rozwoju intelektualnym. Konstantemu Skirmunttowi żali się:

Pisał Pan [...], że listy moje będą kiedyś czytane przez kogóś, kto po mnie, o mnie pisać zechce. Nie spodziewam się tego. Powieściopisarze szybko przemijają. [...] Nie przejdą do potomności książki moje, a tym bardziej listy. Nie spodziewam się i nie pragnę tego ${ }^{16}$.

\footnotetext{
9 Ibidem, s. 359.

10 E. Orzeszkowa, Listy zebrane, t. 5, Wrocław 1961, s. 92-93.

11 Por. ibidem, s. 15: „Pokoje puste i jak grób ciche, dusza smutna”.

12 E. Orzeszkowa, Listy zebrane, t. 3, s. 142.

13 E. Orzeszkowa, Listy zebrane, t. 4, s. 192.

14 E. Orzeszkowa, Listy zebrane, t. 5, s. 130.

15 M. Skiba, op. cit., s. 365, 369.

16 E. Orzeszkowa, Listy zebrane, t. 9, s. 251.
} 
Jeszcze większym rozgoryczeniem przepełnione są słowa, które kreśli w liście do Tadeusza Bochwica: „napadły mię w czasach ostatnich dnie, w których jestem [...] do niczego. Nienawidzę siebie samą w dniach takich [...]"17. W deprecjonowaniu własnej osoby i własnych zasług niektórzy badacze dopatrują się toposu afektowanej skromności - „a ponieważ oprócz bazgrania nic porządnie robić nie umiem, więc wtedy tylko, kiedy bazgrzę, nie czuję się drzewem do spalenia tylko zdatnym albo pyłem zdeptania tylko godnym"18 — ale jest to raczej autentyczne poczucie bycia ,pustym chwastem”, zawsze niewystarczająco dobrą, zbyt przeciętną, towarzyszące Orzeszkowej przez całe życie.

Szczególnie ciekawym, a przy tym niezwykle istotnym studium samotności jest osobisty dziennik pisarki. Przywołując spostrzeżenia Barbary Olech, „Dnie Orzeszkowej można [...] traktować jako exemplum ludzkiej samotności, a ta jak wiadomo - ma wymiar ponadczasowy" ${ }^{\prime 19}$. Dnie odnalezione zostały w 1958 roku w archiwum wileńskim przez Edmunda Jankowskiego, który poinformował o swoim odkryciu na łamach „Twórczości”. W dzienniku tym, zatytułowanym przez samą Orzeszkową, zawarła ona zapiski schyłkowych lat swojego życia: 1898-1904. Rozpoczęła jego prowadzenie rok po śmierci wieloletniego towarzysza, a później męża, Stanisława Nahorskiego, którego odejście mocno przeżyła. W liście do Maryli Wolskiej określiła je jako „książkę najosobistszych, najtajemniejszych notatek"20 oraz „tajemny notatnik”21. W przeciwieństwie do Zwierzeń, Wspomnień, Pamiętnika czy Autobiografii w listach Orzeszkowa pisała Dnie dla samej siebie, nie planując ich publikacji. Jest to forma skrajnie minimalistyczna, pozbawiona refleksji, opisu stanów emocjonalnych, do bólu pragmatyczna. Przypomina raczej diarystyczne notatki niż faktyczny dziennik. Zapiski są fragmentaryczne, szczątkowe, pełne trudnych do odszyfrowania skrótów, inicjałów, kryptonimów. Często mijające dni zawarte zostają tylko w pojedynczych wyrazach. Dnie współgrają z rozpadem starzejącego się, chorującego ciała, a jednocześnie, jak pisze Barbara Olech: „Dramat samotności [...] jest w Dniach [...] dramatem kobiecości włączonej w bieg czasu. Orzeszkowa świadomie ucieka od opisu własnej zewnętrzności, zmieniającego się ciała" ${ }^{22}$. Zapiski te są krańcowo różne od jej typowego stylu. Wyraźnie kontrastują z listami, publicystyką czy dziełami literackimi. Urywane, eliptyczne, oszczędne, przedstawiają najgłębszą prawdę o pisarce. Stają się dla niej formą autoterapii. Pokazują jej egzystencjalne zmagania ze starością, samotnością, chorobą, lękiem, bólem, utratą atrakcyjności ${ }^{23}$,

17 E. Orzeszkowa, Listy zebrane, t. 5, s. 185.

18 E. Orzeszkowa, Listy zebrane, t. 7, Wrocław 1971, s. 279.

19 B. Olech, Samotność wśród ludzi. O „,Dniach” Elizy Orzeszkowej, https://bit.ly/2UdNIPW (dostęp: 29.06.2021), s. 100 .

20 E. Orzeszkowa, Listy zebrane, t. 8, oprac. E. Jankowski, Wrocław 1976, s. 286.

21 Ibidem, s. 289.

22 B. Olech, Samotność..., s. 106.

23 B. Olech, Codzienność u schyłku dnia, https://bit.ly/3cYId8L (dostęp: 7.06.2021). 
porządkują codzienność. Być może Orzeszkowa, niezwykle płodna literacko $\mathrm{i}$ intelektualnie, potrzebowała przestrzeni zupełnie przeciwstawnej, pozbawionej jakiejkolwiek refleksyjności. Możliwe, że tylko taka forma pozwalała jej pod koniec życia porządkować siebie. W Dniach mamy bowiem do czynienia z banalną codziennością. Zapiski mają przede wszystkim charakter codziennego podsumowania. Na ich podstawie można odtworzyć przybliżony schemat dnia pisarki. Natłok spraw wydaje się momentami chaotyczny, niemożliwy do ogarnięcia. Jedyną stałą w życiu, jedyną pewnością, staje się dla niej śmierć ${ }^{24}$. Orzeszkowa skrzętnie notuje, kto przychodzi z wizytą, od kogo nadeszła korespondencja, do kogo ona sama nadała listy. Być może ten rodzaj zapisków to także próba potwierdzenia na papierze relacji łączących ją z ludźmi, przekonania siebie samej, że nie jest zupełnie opuszczona. W praktyce jednak samotność nie daje się oszukać. „Nikt i nic opr[ócz] pióra, notuje w Dniach, pracując nad Wozem Żagornanta, [...] Wszyscy zawodzą — wszyscy obcy — tylko śm[ierć] pewna, ale kiedy?"25 Mimo dziesiątków nazwisk przewijających się na kartach Dni pisarka do końca czuje się samotna.

Język, którym Orzeszkowa posługuje się w chwilach silnych emocji, szczególnie tych związanych z uczuciem miłości, nie jest szczególnie oryginalny. Pisarka wykorzystuje raczej kliszowe, utarte zwroty, banał, konwencję. Obszary „niepowiedzianego” są w dzienniku rozleglejsze od tych, które poddały się werbalizacji ${ }^{26}$. Barbara Olech zauważa, że w Dniach dostrzec można dwie role Orzeszkowej - pisarza oraz kobiety, schorowanej, starzejącej się, nieradzącej sobie z upływem czasu. Rola człowieka instytucji, niekończący się natłok spraw, zawłaszcza życie prywatne ${ }^{27}$. Prywatność zostaje sprowadzona do tych właśnie fragmentarycznych zapisków w dzienniku, przeznaczonych już tylko dla samej Orzeszkowej. Pisarka przez większość życia czuła się niezrozumiana, jednak u jego schyłku odczucia te jeszcze bardziej się pogłębiły, przede wszystkim z powodu utraty najbliższego człowieka, jakim był dla niej Nahorski. W Dniach często zwraca się do niego, nazywając go ,cieniem”. Modli się, żeby jak najszybciej znalazła się tam, gdzie on. W jednym z zapisków notuje: „Wszystko to szaleństw[wo] moje, głupstwo i męka. Jakże dawno poszł[abym] z[a] t[obą] c[ieniu], gdyb[ym] nie lęk[ała] się B[oga]! Już nigdy nie powiem ci! Straszna tęsknota!"28. Oprócz dialogu z „cieniem” zapiski są przede wszystkim dialogiem Orzeszkowej z samą sobą. Widzimy więc w nich Orzeszkową mówiącą i Orzeszkową słuchającą ${ }^{29}$. Ta druga odgrywa zdecydowanie istotniejszą rolę. Konstytuuje się w odczuciu coraz większej samotności i niezrozumienia, braku bliskiej osoby, przed którą nie tylko

24 Por. E. Orzeszkowa, Dnie, oprac. I. Wiśniewska, Warszawa 2001, s. 32.

25 Ibidem.

26 Por. B. Olech, Samotność..., s. 103, 109.

27 Ibidem, s. 100.

28 E. Orzeszkowa, Dnie, s. 36.

29 Por. B. Olech, Samotność..., s. 103. 
mogłaby się otworzyć, lecz także jej otwarcie zostałoby zrozumiane i ,zaopiekowane". Orzeszkowa jest świadoma ról, w jakie wchodzi. Nazywając je, próbuje jednocześnie z nimi się rozliczyć.

Rok 1898 zdominowany jest w dzienniku postacią Franciszka Godlewskiego, młodszego od pisarki o 25 lat. Orzeszkowa, wspominając o nim, posługuje się różnymi kryptonimami: „X”, „p. fr.”, „f”, „F”. Usiłuje dzięki tej relacji poradzić sobie z traumą po śmierci Nahorskiego.

Intymny, enigmatyczny dukt dziennika Dnie z lat 1898-1904 stanowi najbardziej wewnętrzny, pozbawiony retuszu wgląd w pejzaż melancholii Orzeszkowej. To świadectwo załamania po śmierci męża oraz pamiętnik emocjonalnego zaangażowania sześćdziesięcioletniej pisarki w relacjach z Franciszkiem Godlewskim; można zatem mówić o melancholii żałoby i o sui generis melancholii miłosnej ${ }^{30}$.

Pięćdziesięciotrzyletnia Orzeszkowa, uznana pisarka, osoba publiczna, autorytet, szuka u niego potwierdzenia własnej atrakcyjności, dopatruje się przejawów zainteresowania wykraczających poza przyjacielskie relacje. Boleśnie przeżywa zawód miłosny, ale jeszcze bardziej chyba dotyka ją upływający czas. Trudno zaprzeczyć sile uczucia łączącego ją ze Stanisławem Nahorskim, równie trudno jednak dopatrzyć się w ich związku wielkiej miłości, o której pisarka całe życie marzyła. Szczególnie rozgoryczona jest po epizodzie niewierności Nahorskiego w 1883 roku. Pisze wówczas do Leopolda Méyeta: „Coś mi takiego w życiu umarło, po czym zdaje się, nie pocieszę się nigdy”, a po kilku dniach: „we wnętrzu swoim jestem tak dalece kobieta, że ani rozkosze pracy twórczej, ani triumfy miłości własnej nie mogą zabić we mnie jadu tej myśli: nie jestem kochaną"31. Nawet jakiś czas później, wspominając o tym wydarzeniu w liście do Henryka Elzberga, żali się: „Jestem już bodaj na zawsze bardzo smutna i mam w sobie strunę niepocieszoną, która płacze i żałosną pieśń śpiewa we mnie zawsze, czy kiedy milczę lub mówię, czy kiedy śmieję się lub pracuję, czy kiedym sama lub z ludźmi" 32 . Relacja z Godlewskim staje się ucieczką od samotności, próbą przekroczenia jej, wyjścia poza. Szczególnie wyraźnie zaznaczone są w dzienniku dni jego nieobecności w domu pisarki. Intensywnie przeżywa ona także sytuacje, w których traktuje ją chłodno, z dystansem. Przyczyn tego doszukuje się we własnym zachowaniu. W zapiskach z 18 lutego, gdy dowiaduje się, że Godlewski nie odwiedzi jej tego dnia, Orzeszkowa notuje: „Męka. Samotność bez granic [...] Opuszcz[enie] moje ogrom[ne]. Bóg jeden ze mną. Nie ma u kogo poradzić się o nic, z nicz[ym] zwierzyć się. Męka!"33. Skrajnie odmienne, choć równie gwałtowne, są jej słowa, kiedy okazuje się, że Godlewski jednak ją odwiedził:

${ }^{30}$ A. Mazur, , Cofanie się i ciemnienie świata”. Melancholia starości w późnym pisarstwie Elizy Orzeszkowej, [w:] Egzystencjalne doświadczenie starości w literaturze, red. A. Gleń, I. Jokiel, M. Szladowski, Opole 2008, s. 236.

31 E. Orzeszkowa, Listy zebrane, t. 2, oprac. E. Jankowski, Warszawa 1955, s. 20.

32 E. Jankowski, op. cit., s. 240.

33 E. Orzeszkowa, Dnie, s. 36. 
„Wiecz[orem] przysz[edł] najl[epszy]! Poradz[ił], chwi[la] skryt[ej] słody[czy], dz[ięki] c[i], B[oże]!"’.

O Tadeuszu Garbowskim, kolejnym mężczyźnie w jej życiu, Orzeszkowa pisze o wiele bardziej oszczędnie. Ta lapidarność koresponduje jednak z coraz bardziej szczątkową formą pozostałych zapisków. Skomplikowany był również charakter jej związku z Tadeuszem Bochwicem, także sporo młodszym, z którym, jak podkreślała, łączyło ją ,pokrewieństwo dusz”. To właśnie on został ostatnim powiernikiem, słuchaczem, tym, który dawał jej namiastkę bliskości. Nie wzajemność była dla pisarki ważna. Orzeszkowa nie potrzebowała rozmówcy, lecz jedynie kogoś, kto poświęciłby jej uwagę i zainteresowanie - nie tylko w kwestiach intelektualnych. Orzeszkowa pragnęła się podobać Bochwicowi również jako kobieta: „Żeby Pan wiedział, jaką dziś mam na sobie ładną, nową sukienkę!"34 — pisała w jednym z listów.

Na osobiste doświadczenia nałożyły się odczucia związane z przełomem wieków, który pisarka postrzegała z perspektywy katastroficznej i apokaliptycznej. W jej późnej twórczości pobrzmiewają echa rodzącego się modernizmu. W 1896 ukazał się zbiór Melancholicy, zawierający utwory z lat 1888-1894, będący odpowiedzią na kryzys idei pozytywistycznych. Pisarka rozważała też zatytułowanie go $Z$ Pomroku. Ten nowelistyczny zbiór analizowany jest w kontekście reakcji na zjawiska końca wieku — pesymizm, dekadentyzm, schopenhaueryzm ${ }^{35}$. Henryk Markiewicz zauważa, że każdy z pierwiastków światopoglądu pozytywistycznego (scjentyzm, monizm przyrodniczy, eudajmonistyczny utylitaryzm) stał się niejako swoją odwrotnością, rozszczepił na dwa przeciwstawne pierwiastki ${ }^{36}$. Bohaterowie zbioru nowel, ogarnięci melancholią, stojący przed egzystencjalnymi dylematami, uwikłani historiozoficznie, szukają lekarstwa na ból istnienia. Orzeszkowa jest wówczas przeciwna postawie pesymistycznej. Jak podkreśla Magdalena Kreft:

Orzeszkowa broni prawa do smutku przed zalewem pesymizmu, prawa do cierpienia przed pozerstwem dekadentów, broni estetyki przed przeestetyzowaniem, dogmatów (religijnych, etycznych, naukowych) przed bezdogmatyzmem, zaś cywilizacji broni przed przecywilizowaniem ${ }^{37}$.

W Przedmowie zadedykowanej Janowi Karłowiczowi pisarka porównuje pesymizm do robaka niszczącego drzewo. Jego przyczyny upatruje w rozczarowaniu, ,przecywilizowaniu” materialną stroną cywilizacji (druga strona to postęp moralny wyznaczający kierunek cywilizacji właściwej ${ }^{38}$ ), przeestetyzowaniu, wpływach ,aglomeratów ludzkich” — wielkich miast. Uważa jednak zawód re-

34 E. Orzeszkowa, Listy zebrane, t. 5, s. 130.

35 A. Mazur, Dzieci Saturna. O „,Melancholikach”, [w:] Poznawanie Orzeszkowej...

36 H. Markiewicz, Dialektyka pozytywizmu polskiego, Warszawa 1965, s. 32.

37 M. Kreft, Koncepcja ,przecywilizowania” w twórczości Elizy Orzeszkowej, „Roczniki Humanistyczne" 53, 2005, z. 1, s. 135.

38 Por. ibidem. 
ligią, nauką, pojęciami etycznymi za przedwczesny. Szuka kolejnych źródeł pocieszenia, szczególnie w pięknie natury, cnocie, sztuce, nauce, pracy, obowiązku.

Pamiętam, niegdyś zapytywał mię Pan — kontynuuje Orzeszkowa w Przedmowie — dla czego opowiadania moje posiadają najczęściej koloryt smutny? Odpowiedziałam: bo życie jest hojnie zaprawione smutkiem. Teraz myślę tak samo i w tych książkach, na których czele stawię drogie imię Pana, opowiadam o tych, którzy tak myślą ${ }^{39}$.

W Melancholikach Orzeszkowa zdaje się szukać remedium na pesymizm, dostrzegać otwory w „ciemnej płachcie”, w kolejnych latach jednak coraz bardziej pogrąża się w przygnębieniu, izolacji, rozczarowaniu modernizmem. W Bilansie literackim, który ukazał anonimowo w „Kraju” w 1891 roku z okazji dwudziestopięciolecia pracy twórczej Orzeszkowej, a którego autorką była ona sama, pisała o kilku zawartych w zbiorze nowelach: ,autorka szuka w nich źródeł toczącego świat dzisiejszy pesymizmu, jako też tych sprężyn życiowych, które nękanych przezeń ludzi na duchu i siłach podnieść mogą"40. Jej zdaniem prawidłowy rozwój cywilizacji powinien polegać na zachowaniu równowagi między dorobkiem materialnym i umysłowym a wzrostem moralnym społeczeństwa ${ }^{41}$. Ta ciemna, materialna strona cywilizacji, „cywilizacja szczęśliwych głupców”, która jawi się Orzeszkowej jedynie jako wzmożony konsumpcjonizm, budzi w niej lęk i niezrozumienie.

dlaczego w świecie dzisiejszym mieści się jednocześnie tak wiele wiedzy i tak wiele złości, [...] tak wiele teorii o pięknie i dzieł piękna i jednocześnie tak wiele szpetoty w uczuciach i czynach. [...] A jeżeli nauka i sztuka są z natury swej czynnikami uszlachetniającymi, dlaczego nie uszlachetniają dzisiejszego świata? ${ }^{42}$

W swojej późnej twórczości krytykuje nadmiar, przesyt, hedonizm, szczęście rozumiane jako posiadanie ${ }^{43}$ :

przeciw poczuciu własnej małości bronić się dobrowolnym, pokornym zrzeczeniem się wielkości i słuchać głosu Bożego, który w każdym z nas przemawia, co i jakim narzędziem czynić ma, lecz nieraz bywa przytłumionym przez różne głosy inne, najczęściej przez głos pychy, z ogromną słusznością umieszczonej w katechizmie na czele wszystkich grzechów ${ }^{44}$.

Orzeszkowa wyraźnie rozgranicza pesymizm od smutku i cierpienia, które stanowią jej zdaniem niezbędny element życia prowadzący do rozwoju moralnego. Podkreśla, że:

39 E. Orzeszkowa, Przedmowa, [w]: eadem, Melancholicy, t. 1, Warszawa 1949.

40 E. Orzeszkowa, Bilans literackie Elizy Orzeszkowej, [w:] eadem, Pisma krytycznoliterackie, oprac. E. Jankowski, Wrocław-Kraków 1959, s. 587.

${ }^{41}$ M. Kreft, op. cit., s. 130.

42 E. Orzeszkowa, Odezwa do Polskiej Partii Socjalistycznej, [w:] eadem, Listy zebrane, t. 4, s. 401 .

43 M. Kreft, op. cit., s. 131.

44 E. Orzeszkowa, Listy zebrane, t. 4, s. 92, za: I. Wiśniewska, Biografia jako język. Eliza Orzeszkowa, [w:] Pozytywizm. Języki epoki, red. G. Borkowska, J. Maciejewski, Warszawa 2001, s. 164. 
Jednak pomimo to wszystko, pomimo, że jeden gatunek pesymizmu może być ukojony brzękiem mamony, lub fanfarą sławy, a drugiemu zaprzeczy bliższa lub dalsza przyszłość, nie przestaje być prawdą, że życie jest hojnie zaprawione smutkiem. Nic nie zdoła uwolnić go od trzech głównych postrachów reformatora indyjskiego: od choroby, starości i śmierci; nikt nie zdoła zapobiec wrodzonym nierównościom cielesnym i duchowym, ani odegnać z przed oczu żyjących widma znikomości. Srogość rzeczy ludzkich może ulec znakomitym zmniejszeniom; lecz tą z nich, która nie zniknie nigdy jest — ich znikomość.

Smutek jest dla niej czymś, co tkwi głęboko w człowieku, towarzyszy mu na każdym kroku, nie ma przyczyny. Nie można go ukoić ani przez powrót do praw naturalnych czy ewangelicznych, ani przez sam kontakt z nieskażoną cywilizacją naturą, ani nawet poprzez miłość i ofiarę ${ }^{45}$. Magdalena Kreft, definiując cierpienie w rozumieniu Orzeszkowej, podkreśla, że jest ono czynnikiem niezbędnym do właściwego kształtowania ludzkiej egzystencji, gdyż ocala słabość przed triumfem siły ${ }^{46}$. „Najpewniej też cierpimy nie nadaremnie — pisze Orzeszkowa — na jakimś olbrzymim warsztacie jesteśmy kółkami, biorącemi udział w dokonywaniu dzieła niepojętego, a nasze cierpienia spełniają jakąś czynność dla warsztatu, dla nas i dla dzieła" ${ }^{47}$. W tym okresie przewartościowuje swój dotychczasowy światopogląd. Fundamentem jej osobistej filozofii staje się wiara w Boga — współczującego pocieszyciela i moralny drogowskaz. Czasem wartościowym jest dla niej czas twórczy, okres pisania. Ustanie w pracy nazywa próżniaczeniem. W liście do Aurelego Drogoszewskiego pisze:

„woli życia” nie mam, owszem, bywają chwile, nierzadkie, w których mam raczej „wolę śmierci”. Ale istnieje we mnie jakiś imperatyw nieprzezwyciężony, który nie pozwala na bezczynność ani na obojętność, ani na senność — dopóki żyję. Cóś mię popycha, cóś mię napędza, cóś mię rwie do pośpiechu $^{48}$.

Zwraca się ku ascezie. Pisze o pokornym godzeniu się z losem, a nawet obowiązku rezygnacji ze szczęścia: „bez szczęścia obejść się można, niekiedy nawet święcie należy"49. Sensu życia poszukuje w relacjach z bliskimi, pracy literackiej i miłości do natury. Ten system poglądów towarzyszący Orzeszkowej w ostatnim okresie Stanisław Fita określa mianem „chrześcijański pozytywizm” ${ }^{50}$.

Pod koniec lat dziewięćdziesiątych Orzeszkowa zaczyna cierpieć na chorobę niedokrwienną serca — angina pectoris — nazywaną dawniej dusznicą bolesną czy też dławicą piersiową. Jesienią 1903 roku notuje w Dniach: „Noc b[ardzo] zła. Czy przybli[ża] się już kon[iec]? W dz[ień] lep[iej], ale słabo i obaw[a]

45 P. Śniedziewski, Pozytywistyczne spleeny — „,Melancholicy” Elizy Orzeszkowei, „Pamiętnik Literacki" 2009, nr 4, s. 53-71.

46 M. Kreft, op. cit., s. 137.

47 E. Orzeszkowa, Przedmowa...

48 E. Orzeszkowa, Listy zebrane, t. 4, s. 150.

49 E. Orzeszkowa, Listy zebrane, t. 8, s. 252.

50 S. Fita, Eliza Orzeszkowa w poszukiwaniu religii, [w:] Problematyka religijna $w$ literaturze pozytywizmu i Młodej Polski. Świadectwa poszukiwań, red. S. Fita, Lublin 1993, s. 89. Por. J. Święcicki, ,Bez dogmatu” Orzeszkowej, „Tygodnik Powszechny” 1947, nr 12. 
nocy, o któr[ej] nie m[a] kom[u] powiedz[ieć]. Straszn[a] samotn[ość]! Myślę, że umieraj[ąc], nie będę miała p[rzy] sob[ie] ani jedn[ej] ist[oty] prawdz[iwie] kochaj[ącej] i kochan[ej]. Myślę, czy zasłuż[yłam] na to?"51. Lata 1906-1910 to czas coraz poważniejszych problemów zdrowotnych pisarki. Skarży się na kłopoty z sercem, pogarszający się wzrok, bóle ręki, doświadcza halucynacji, a to prowokuje liczne pytania egzystencjalne. Pod koniec życia nie cieszy jej nawet kolejny, choć nieco feralny pod względem organizacyjnym, jubileusz — czterdziestolecia pracy literackiej (ostatecznie pisarka w nim nie uczestniczy) ani nominacja do Literackiej Nagrody Nobla, której jednak nie otrzymuje. ,Jubileusz! — pisze — Deszcz listów, odezw, żądań, komplimentów w formach tysięcznych i obowiązek odpowiadania, dziękowania etc. A wrażenia jakie? [...] Powtarza mi się w pamięci wiersz Wyspiańsk[iego]: „Słowa! Słowa! Słowa!«"52. Orzeszkowa coraz wyraźniej zauważa proces przemijania, swoje własne starzenie się, zmiany zachodzące w otoczeniu: „Tak dnie cieką, jeden za drugim, jak paciorki różańca, coraz bliżej ku krzyżowi, który jest jego zamknięciem" $" 53$.

Samotność Orzeszkowej jest jednocześnie samotnością szokująco wręcz bolesną, ale i samotnością twórczą ${ }^{54}$. Właśnie $\mathrm{z}$ tej samotności biorą się dojrzałe dzieła pisarki. Z późnych utworów Orzeszkowej przemawia jej własne rozczarowanie, wieczne poczucie niedocenienia. Dużo w tych tekstach cierpienia, rozpaczy, rezygnacji. W jej wyznaniach część badaczy doszukuje się egzaltacji, teatralności. Magdalena Kreft w autobiografii pisarki, odwołując się do jednego z listów, zauważa: „Trudno uwierzyć jej skargom na samotność i opuszczenie o godzinie 12.00 , gdy o 16.00 przyszło do niej jedenaście osób na kilkugodzinne spotkanie" ${ }^{\text {55 }}$. Podobnie pisze w recenzji książki Franciszka Godlewskiego Pani Orzeszkowa Władysław Tołłoczko: „ściśle mówiąc, Orzeszkowa otoczona szczelnie licznym fraucymerem i liczniejszym jeszcze kołem adoratorek i adoratorów, nie była bynajmniej samotną" ${ }^{56}$. Jednak Orzeszkowej brakuje nie spotkań, lecz relacji, intymnej więzi, możliwości otwarcia się przed drugim człowiekiem. Najbardziej samotna jest właśnie dlatego, że niemal ciągle otaczają ją ludzie, liczne grono, dla którego jest raczej instytucją niż konkretną jednostką. Dotkliwie odczuwa brak rodziny, w dodatku jej najbliżsi przyjaciele, Maria z Siemaszków i Maksymilian Obrębscy, w 1902 roku zostają przeniesieni do Saratowa, a dwa lata później do Wilna. Po śmierci Nahorskiego w listach jeszcze więcej jest mowy o smutku, łzach, żalu. Siedem miesięcy po jego odejściu pisze w liście do Méyeta:

51 E. Orzeszkowa, Dnie, s. 306.

52 E. Orzeszkowa, Listy zebrane, t. 3, s. 339.

53 E. Orzeszkowa, Listy zebrane, t. 5, s. 300.

54 Por. J. Wadowski, Samotność jako szansa - droga do doskonałości i spetnienia, [w:] Zrozumieć samotność. Studium interdyscyplinarne, red. P. Domeradzki, W. Tyburski, Toruń 2006, s. 238.

55 M. Kreft, Przypis 29, [w:] eadem, Śmierć białych motyli, Eliza Orzeszkowa: biografia, wyobraźnia, idee, Gdańsk 2019, s. 144.

56 Gardiner [W. Tołłoczko], „Pani Orzeszkowa” [recenzja książki F. Godlewskiego Pani Orzeszkowa], „Przegląd Wileński” 1933, nr 17; za: I. Wiśniewska, op. cit., s. 169. 
Chwilami nie podobna mi uwierzyć, że ta Eliza Orzeszkowa, która tam nad Niemnem mieszkała, która jubileusz obchodziła, do Warszawy przyjeżdżała — i ja, to jedna i ta sama osoba. Cóś tak głęboko złamało się we mię, że mię rozdwoiło: tam była kobieta żywa, autorka działająca, gospodyni domu wesoła i gościom rada — tu cień jakiś, z rysów i nazwiska do tamtej podobny. Właściwie żyję, bo muszę, pracuję, bo nie mam co z sobą i ze swymi dniami zrobić, rozmawiam z ludźmi, bo do grzeczności i życzliwego obejścia się przywykłam, ale w tym wszystkim prawdziwego życia nie ma. Skupiło się ono tylko już we wspomnieniach i w żalu ${ }^{57}$.

W 1906 roku Maria Czesława Przewóska zwraca się do pisarki z prośbą o nieco szczegółów biograficznych na potrzeby wydawnictw jubileuszowych. W odpowiedzi Orzeszkowa pisze:

w ostatnich latach 15-tu rzeczywiście nic się ze mną nie działo i nie stawało takiego, co by dla ogółu było ciekawym albo do dowiedzenia się potrzebnym. Jak człowiek każdy miałam przez czas ten swoje smutki i pociechy, nadzieje i zawody, straty i zdobycze, ale co to wszystko może kogo obchodzić? I nic rzeczywiście z tego, co mnie osobiście dotyka, nikogo nigdy nie obchodziło. Nikt nigdy nie interesował się losem moim, ani tym, jak i czy żyję ${ }^{58}$.

Słowa te, pełne rozgoryczenia, wydają się mimo wszystko niesprawiedliwe i dalekie od prawdy. Pokazują jednak zły stan psychiczny pisarki i nieustannie towarzyszące jej poczucie osamotnienia. Orzeszkowa miała w sobie pewien rodzaj pustki, której nie zdołała wypełnić ani działalnością społeczną, ani kontaktem z naturą, ani metafizyką, ani nawet pisaniem, chociaż było dla niej ,opiumem, który usypia bóle, hatchisem [!], który tęsknotę czerwoną przerabia na złote sny..."59. Krótko przed śmiercią, będąc już bardzo schorowaną, Orzeszkowa stworzyła jeszcze ostatni aforyzm, który ukazał się w „Tygodniku Mód i Powieści”:

Człowiek jest nurkiem, szukającym pereł w gorzkim morzu życia, a gdy wody gorzkie pierś mu zalewają i na dnie ich rozlega się ciemność, jakże trudno mu prawdziwą od fałszywej, żywą od umarłej perłę odróżnić!

Henryk Nausbaum, warszawski lekarz, napisał po śmierci pisarki, komentując jej stan zdrowia: „W niej sprawdziło się raz jeszcze, że długotrwałe, głębokie, moralne cierpienie serca powodują organiczne w tym mięśniu chorobowe zmiany [...]"60.

Trzynaście lat przed śmiercią, w 1897 roku, Orzeszkowa zaprojektowała i ufundowała nagrobek dla siebie i męża. Często odwiedzała ich wspólny grób ${ }^{61}$. Na pomniku kazała umieścić dwuwiersz z Psalmu 7 w thumaczeniu Jana Kochanowskiego.

\section{W Tobie ja samym, Panie, człowiek smutny, Nadzieję kładę. Ty racz o mnie radzićc ${ }^{2}$.}

57 E. Orzeszkowa, Listy zebrane, t. 2, s. 129-130.

58 E. Orzeszkowa, Listy zebrane, t. 4, s. 235, za: I. Wiśniewska, op. cit., s. 166.

59 E. Jankowski, op. cit., s. 609.

60 Ibidem, s. 624.

61 M. Kreft, Śmierć..., s. 187.

62 J. Kochanowski, Dzieła polskie, oprac. J. Krzyżanowski, Warszawa 1989, s. 308, cyt. za: M. Kreft, Śmierć..., s. 188. 


\section{Bibliografia}

Danek D., Prawdziwa Eliza Orzeszkowa (w świetle nowego wydania autobiografii pisarki), [w:] Eliza Orzeszkowa. Pamięć kultury, red. J. Ławski, S. Musijenko, Białystok-Grodno 2019.

Drogoszewski A., Eliza Orzeszkowa, [w:] E. Orzeszkowa, Pisma, t. 1, Warszawa 1912.

Fita S., Eliza Orzeszkowa w poszukiwaniu religii, [w:] Problematyka religijna w literaturze pozytywizmu i Młodej Polski. Świadectwa poszukiwań, red. S. Fita, Lublin 1993.

Jankowski E., Eliza Orzeszkowa, Warszawa 1988.

Kreft M., Koncepcja „przecywilizowania” w twórczości Elizy Orzeszkowej, „Roczniki Humanistyczne" 53, 2005, z. 1.

Kreft M., Śmierć białych motyli. Eliza Orzeszkowa: biografia, wyobraźnia, idee, Gdańsk 2019.

Lubas-Bartoszyńska R., Pisanie autobiograficzne w kontekstach europejskich, Katowice 2003.

Markiewicz H., Dialektyka pozytywizmu polskiego, [w:] Proces historyczny w literaturze i sztuce, red. M. Janion, A. Piorunowa, Warszawa 1967.

Markiewicz H., Literatura okresu pozytywizmu w perspektywie polskiej i światowej, „Pamiętnik Literacki” 53, 1962, z. 3, https://bit.ly/3gJAilu.

Mazur A., „Cofanie się i ciemnienie świata”. Melancholia starości w późnym pisarstwie Elizy Orzeszkowej, [w:] Egzystencjalne doświadczenie starości w literaturze, red. A. Gleń, I. Jokiel, M. Szladowski, Opole 2008.

Mazur A., Dzieci Saturna. O „Melancholikach”, [w:] Poznawanie Orzeszkowej. W stulecie śmierci 1910-2010, red. I. Sikora, A. Narolska, Częstochowa-Zielona Góra 2010.

Mazur A., Pod znakiem Saturna. Topika melancholii w późnej twórczości Elizy Orzeszkowej, Opole 2010.

Olech B., Codzienność u schytku dnia, https://bit.ly/3cYId8L.

Olech B., Samotność wśród ludzi. O „Dniach” Elizy Orzeszkowej, https://bit.ly/2UdNlPW.

Orzeszkowa E., Anastazja, [w:] eadem, Anastazja ... I pieśń niech zapłacze, Warszawa 1977.

Orzeszkowa E., Bilans literackie Elizy Orzeszkowej, [w:] eadem, Pisma krytycznoliterackie, oprac. E. Jankowski, Wrocław-Kraków 1959

Orzeszkowa E., Dnie, oprac. I. Wiśniewska, Warszawa 2001.

Orzeszkowa E., Listy zebrane, t. 1-9, oprac. E. Jankowski, Wrocław 1954-1981.

Orzeszkowa E., Melancholia i poznanie. „Autobiografie” Elizy Orzeszkowej, oprac. D. Danek, Warszawa 2014.

Orzeszkowa E., O sobie..., red. J. Krzyżanowski, Warszawa 1974.

Orzeszkowa E., Odezwa do Polskiej Partii Socjalistycznej, [w:] Listy zebrane, t. 4, Wrocław 1958.

Orzeszkowa E., Przedmowa, [w]: eadem, Melancholicy, t. 1, Warszawa 1949.

Orzeszkowa E., Wesele Wiesiołka, [w:] eadem, Chwile, Warszawa 1901.

Skiba M., O życiu, cierpieniu i śmierci. Epistolograficzne rozważania egzystencjalne Orzeszkowej, [w:] Poznawanie Orzeszkowej. W stulecie śmierci (1910-2010), red. I. Sikora, A. Narolska, Częstochowa-Zielona Góra 2010.

Szcześniak J., Dylematy egzystencjalne w „Melancholikach” Elizy Orzeszkowej, [w:] Twórczość Elizy Orzeszkowej, red. K. Stępnik, Lublin 2001.

Śniedziewski P., Pozytywistyczne spleeny — „Melancholicy” Elizy Orzeszkowei, „Pamiętnik Literacki" 2009, nr 4.

Wadowski J., Samotność jako szansa - droga do doskonatości i spetnienia, [w:] Zrozumieć samotność. Studium interdyscyplinarne, red. P. Domeradzki, W. Tyburski, Toruń 2006.

Wiśniewska I., Biografia jako język. Eliza Orzeszkowa, [w:] Pozytywizm. Języki epoki, red. G. Borkowska, J. Maciejewski, Warszawa 2001.

Zeller I., Eliza Orzeszkowa wobec filozofii pesymizmu przełomu wieków, https://bit.ly/3wMwCkT. 


\section{Loneliness of the heart and loneliness of thoughts}

\section{Summary}

The article is a study of the melancholic nature of Eliza Orzeszkowa, an attempt to notice Orzeszkowa not as a writer, but an unhappy woman. The main aim is to show the sorrow at different times in her life. Difficult events from her biography were recalled in the article. Paying attention to such issues allows us to better understand the creations of the heroes in her literary works especially distanced, snippy mothers. Selected works, letters and the diary Dnie were analysed. Orzeszkowa spent almost all her life in the region of her origin. The first painful experiences for her were the remarriage of her mother and then the death of her sister. The arranged marriage with Piotr Orzeszko did not last long. Also, she did not find happiness in her long-term relationship with Stanisław Nahorski. She constantly missed love. Although Orzeszkowa was appreciated as a writer (she was nominated for the Nobel Prize in Literature twice), lifelong she felt inferior and sometimes even hated herself. From childhood she experienced states of melancholy. Her house in Grodno (where she was interned) was always full of guests - loved ones, friends, readers, pupils; however, her letters and the diary are the testimony of a deep solitude, and the experience of sadness is in almost all of her works.

Keywords: Eliza Orzeszkowa, 19th century, isolation, loneliness, solitude, biography, senility, illness, melancholy, sorrow, loss 